\title{
Canada makes plans for defence of its Arctic territories
}

\section{Washington}

Concern over Canada's plan to purchase a multi-billion dollar fleet of nuclear attack submarines from Britain or France was voiced in the US Senate Armed Services Committee last week. If the submarines come from Britain, permission will have to be sought for the transfer of US nuclear propulsion technology.

According to Senator James Exon (Democrat, Nebraska) the implications of the transfer have not been fully examined.

The new fleet's purpose is to defend Canadian and NATO sea lanes against Soviet submarines, and to keep Canada's Arctic Ocean free from hostile intruders. But the stimulus that triggered the decision was incursions by US, rather than Soviet, vessels into waters claimed by Canada.

In dispute between the United States and Canada is the famed Northwest Passage which connects the Pacific and the Atlantic through Amundsen Gulf, Prince of Wales Strait, Viscount Melville Sound and Lancaster Sound. Although the passage is only 20 miles wide where it winds between Banks Island and Victoria Island, both part of Canada's Northwest Territories, the United States regards the Northwest Passage as an international waterway over which Canada does not have jurisdiction. The US view is that accepting this claim would open the door to others, including that of Libya's

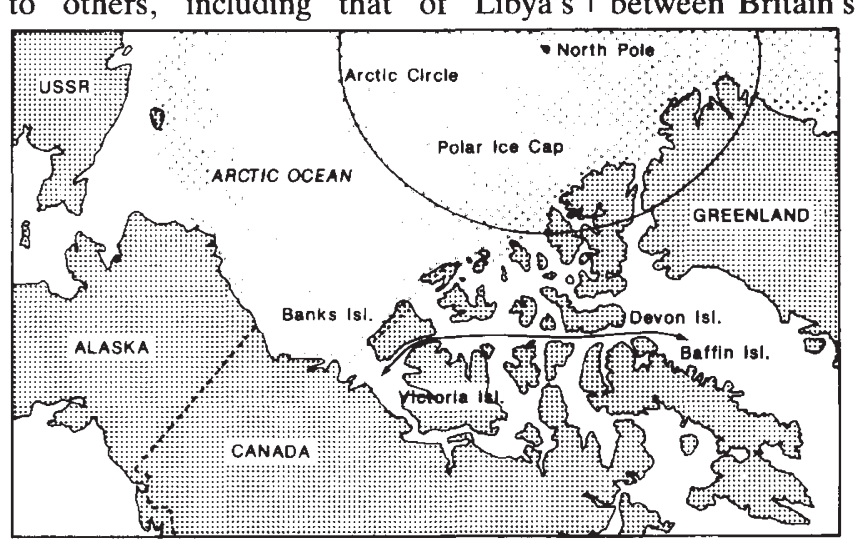

Canada's greatest concern is that it would be powerless if nuclear armed submarines used Canadian waters to pass between Atlantic or Pacific, or simply to hide out of sight under the Arctic ice. So far, there is no evidence that Soviet submarines, which might want to pass through Canadian waters to avoid the closely guarded seas around Iceland, have violated Canadian sovereignty. But US submarines seem to have done so. In 1986 , three US attack submarines surfaced at the North Pole, and at least one of them must have passed among Canada's Arctic islands to get there.

Negotiations between the United States and Canada have failed to settle the issue satisfactorily. An Arctic Cooperation agreement was signed in January this year which pledged that US ice breakers would not again enter "waters claimed by Canada" without "the Consent of the Government of Canada". But the agreement conceded nothing on Canada's demands of sovereignty over the Northwest Passage.

The Canadian government's conclusion is that it must ensure that it has the means to patrol the Arctic waters. A plan to build the world's largest ice breaker, able to operate year round in the Arctic, has been announced. And to ensure that it can see under the ice, Canada wants a fleet of nuclear submarines. The choice is between Britain's Trafalgar class, which are more expensive but better able to break through ice, and France's Rubis class. Both countries are pursuing the multibillion dollar contract vigorously.

The United States supports Canada's increased commitment to defence spending, which has been one of the lowest in NATO, but it would prefer to

Colonel Gadhafi in the Gulf of Sidra.

The dispute was largely academic until August 1985. Then the US Coast Guard sent its massive icebreaker, Polar Star, from the Atlantic to Alaska through the Northwest Passage without asking the Canadian government for permission for the voyage. The United States simply informed Canadian authorities the trip would take place. That was sufficient to alert the Canadian government that as Prime Minister Brian Mulroney put it, they did not have "so much as a canoe" with which to assert their sovereignty over the Arctic territories. see the money go on conventional forces in Europe. And now, faced with the possibility that the first purchase order might be made as early as June, the US government is beginning to worry about the implications of a submarine sale.

If British submarines are ordered, then US technology will have to be employed. That will raise new questions of the transfer of highly secret technology. And there is, according to Senator Exon, the risk that even a minor accident in a USpowered Canadian submarine could result in US submarines being banned from foreign ports. But, although these matters

\section{French plans to revise doctorate}

Paris

FACED with the greater internationalization of research and the dominance of English as the international lingua franca, at least in science, France decided, in 1984, to make its two-tier doctorate more like the English and US PhD. However, life in a country that pays little regard to titles, but rates scholarly pursuits highly, could not be that simple. In reforms which could become effective before the May presidential elections, science and higher education minister, Jacques Valade, is planning to revive some aspects of the previous system.

As is still the case in some European countries the French used to have two doctorates. The first, taken after the Diploma of Advanced Education (DEA), qualified the candidate to undertake independent research. In some disciplines, notably arts and humanities, a further period of directed research was necessary before a postdoc could supervise research or hold a senior university post.

The second doctorate - the Thèse d'Etat, or State Doctorate - was awarded after a long period of research under the paternal scrutiny of a supervisor and was seen by some as the culmination of a life's work. In 1984 the Thèse d'Etat was abandoned and the 'third cycle' doctorate upgraded to a PhD equivalent, based on three or four years' supervised research.

In 1986 Alain Devaquet, then research and higher education minister in the newly elected conservative government, proposed a series of university reforms, including the reintroduction of the Thèse d'Etat. This latter move was encouraged by old-guard university professors, close to senior cabinet ministers in the new government, who had seen their 'mandarin' status eroded by the more democratic $\mathrm{PhD}$.

When Devaquet's proposed reforms produced student riots and his subsequent resignation, plans to return to a two-tier doctorate were put on the back burner. Now, under pressure once again from right-wing academics, Valade is planning to bring back the Thèse d'Etat, under a different name. Essentially, the postdoctoral qualifiying period leading to admission to the academic community would involve further supervised research and, possibly, another thesis. The changes will initially apply only to arts and humanities; the science $\mathrm{PhD}$ will not be affected for the time being. Peter Coles

are sure to be considered, the final decision on a transfer of technology is bound to depend more on the political relationships between the two countries. Prime Minister Mulroney is due to visit US President Ronald Reagan in Washington this week.

Alun Anderson 